International Journal of Environmental Research and

Public Health

ISSN 1660-4601

www.mdpi.com/journal/ijerph

Article

\title{
Inventory of Engineered Nanoparticle-Containing Consumer Products Available in the Singapore Retail Market and Likelihood of Release into the Aquatic Environment
}

\author{
Yuanyuan Zhang, Yu-Rui Leu, Robert J. Aitken and Michael Riediker *
}

SAFENANO, IOM Singapore, 30 Raffles Place, \#17-00 Chevron House, Singapore 048622, Singapore; E-Mails: Zhang.Yuanyuan@iom-world.sg (Y.Z.); owenleu@hotmail.com (Y.-R.L.); rob.aitken@iom-world.sg (R.J.A.)

* Author to whom correspondence should be addressed; E-Mail: michael.riediker@iom-world.sg; Tel.: +65-6809-6249.

Academic Editor: Mónica Amorim

Received: 1 July 2015 / Accepted: 20 July 2015 / Published: 24 July 2015

\begin{abstract}
Consumer products containing engineered nanoparticles (ENP) are already entering the marketplace. This leads, inter alia, to questions about the potential for release of ENP into the environment from commercial products. We have inventoried the prevalence of ENP-containing consumer products in the Singapore market by carrying out onsite assessments of products sold in all major chains of retail and cosmetic stores. We have assessed their usage patterns and estimated release factors and emission quantities to obtain a better understanding of the quantities of ENP that are released into which compartments of the aquatic environment in Singapore. Products investigated were assessed for their likelihood to contain ENP based on the declaration of ENP by producers, feature descriptions, and the information on particle size from the literature. Among the 1,432 products investigated, 138 were "confirmed" and 293 were "likely" to contain ENP. Product categories included sunscreens, cosmetics, health and fitness, automotive, food, home and garden, clothing and footwear, and eyeglass/lens coatings. Among the 27 different types of nanomaterials identified, $\mathrm{SiO}_{2}$ was predominant, followed by $\mathrm{TiO}_{2}$ and $\mathrm{ZnO}$, Carbon Black, Ag, and Au. The amounts of ENP released into the aquatic system, which was estimated on the basis of typical product use, ENP concentration in the product, daily use quantity, release factor, and market share, were in the range of several
\end{abstract}


hundred tons per year. As these quantities are likely to increase, it will be important to further study the fate of ENP that reach the aquatic environment in Singapore.

Keywords: nano-inventory; engineered nanoparticles (ENP); emission quantity; aquatic environment

\section{Introduction}

With the rapid development of nanotechnology, engineered nanoparticles (ENP) are being used in a widening range of industrial sectors and commercial products. ENP are being increasingly used in catalysts, cosmetics and personal care products, pharmaceutical and medical applications, lubricants and fuel additives, paints and coatings, construction materials, chemical and biological sensors, optics and optical devices, food processing and packaging, agrochemicals, textiles and clothing, detergents, security and authentication applications, UV-absorbers and free-radical scavengers, plastics, weapons and explosives, and in countless other products and materials [1-4]. ENP have also been used for water treatment and environmental remediation (e.g., nano-Fe, $\mathrm{TiO}_{2}, \mathrm{Ag}$ ), which may be associated with the release of ENP into aquatic environment [5-7]. Several reviews have reported that nanoscale materials are being used in a widening range of industrial sectors and have made estimates of quantities of commercial scale production and use of nanoscale materials. In a review at the early stage of nanomaterial developments, the Royal Society and Royal Academy of Engineering estimated the production of nanomaterials and predicted the quantities used in various application areas such as structural application (e.g., ceramics, catalysts, coatings, powders, and metal) at 10 tons in 2003-2004, and predicted it to increase to 1000 tons by 2010 and between 10,000 and 100,000 tons per year by 2020 [8]. Aitken et al., (2006) indicated that the main applications of nanomaterials in the UK were in catalysts, lubricants and fuel additives, paints, cosmetics and personal care products (e.g., sunscreens), drug delivery, electronics and sensor devices, functional coatings (e.g., on glass, textiles), etc. [3]. Schmid and Riediker (2008) reported that $\mathrm{Ag}, \mathrm{Al}-\mathrm{O}_{\mathrm{x}}, \mathrm{Fe}-\mathrm{O}_{\mathrm{x}}, \mathrm{SiO}_{2}, \mathrm{TiO}_{2}$ and $\mathrm{ZnO}$ were used in considerable quantities ( $>1000 \mathrm{~kg} /$ year per company) in Swiss industries [9]. A 2010 report by the Dutch government suggested that the number of nano-enabled consumer products had tripled since 2006, though they realized that many of these products were no longer labeled as containing nano [4].

The rapid growth of utilization of ENP in commercial products has triggered concerns on the health and safety, environmental, ethical, policy, and regulatory aspects. These concerns were expressed early on, in the review by the Royal Society and the Royal Academy of Engineering in 2004 [8], and subsequently in many related articles [2,10-13]. Consideration of the application patterns suggests that ENP present in a bonded, fixed, or embedded form may not pose a risk to consumers' health or to the environment during their life cycles. Some applications, on the other hand, may pose a greater potential risk of exposure than others. Of particular concern are those processes, products, and applications that involve large commercial scale manufacturing, use, and disposal of ENP-containing products. Some of these may lead to direct human exposure to ENP via inhalation (e.g., cleaning aids, spray cosmetics, coatings), dermal exposure (e.g., cosmetics), oral ingestion (e.g., food and drink), or intravenous routes (e.g., medicine and diagnostic aids). The estimation of direct exposure in such 
cases has to some extent been achievable [14-17]. In contrast, the estimation of indirect exposure (e.g., via drinking ENP-containing water or through the food chain) through environmental routes remains highly challenging. These indirect exposures may arise from a release of ENP into the environment (i.e., air, water and soil) during the manufacturing process, use, and disposal of ENP-containing products (e.g., water treatment facilities, ship exterior paint, food processing, and personal care products).

To date, little is known about the occurrence, fate, and toxicity of ENP in the environment. In part this is due to the lack of sufficiently sensitive and interference-free methodology for the quantitative and qualitative detection of ENP in a complex matrix, such as the water environment [18]. Given these challenges with analytical techniques, it is important to be able to model or estimate the amount of ENP released into different aquatic environments to support the assessment of the risk to human exposure to ENP-contaminated water and to provide information on ENP behavior in water for regulatory decision-making. Estimates of the distribution and usage of ENP-containing consumer products in daily activities, the release routes, and the environmental fate and behaviors of ENP and therefore indirect human exposure to ENP, not only contribute to regulatory decision-making but also allow the development of suitable experimental approaches to test ENP in complex environmental matrices and help define appropriate instrument detection limits. The objective of this project was to understand the distribution and use of ENP in consumer products available in the Singapore retail market through a nano-inventory and to estimate the possible amount of each identified ENP reaching the aquatic environment based on ENP concentrations in consumer products, market share, and estimated release quantities.

\section{Methods}

\subsection{Nano-Inventory}

For the purpose of this study, the definition of ENP was based on the definition of nanomaterials recommended by the European Commission: a natural, incidental, or manufactured material containing particles in an unbound state or as an aggregate or as an agglomerate and where, for $50 \%$ or more of the particles in the number size distribution, one or more external dimensions is in the size range 1-100 nm. In specific cases and where warranted by concerns for the environment, health, safety, or competitiveness, the number size distribution threshold of $50 \%$ may be replaced by a threshold between $1 \%$ and $50 \%$ [19]. The inventorization of products containing ENP in the Singapore retail market was carried out through the following steps:

(1) Identify product categories that are likely to contain nanomaterials: The application of ENP in consumer articles described in a selection of recent review articles and reports was first briefly reviewed. The identified use types then guided the subsequent inventorization of products in the Singapore consumer market.

(2) Visit stores to identify products of these categories: This nano-inventory was created by visiting stores of all major retailers in Singapore (NTUC xtra, Giant hyper, Sheng Siong, Cold Storage and Watson), and a series of cosmetic stores. Products purchased by individuals abroad or via the internet were not considered, neither were products used for occupational purposes. 
(3) Identify products that are "confirmed" to contain nanomaterials: A product was considered as "confirmed" to contain nanomaterials if either the producer declared the use of nanomaterials on their product's label; if the ingredients listed suggested that they contain nanomaterials; or if there was a match between the product name with online information on websites of major companies (e.g., Sasa, Sephora, Chanel, L'Oréal, Clarins, Shu Uemura, etc.), the statistics database on medical care products of the Singapore Health Science Authority (HSA), or the Woodrow Wilson Institute database [20]. A product was also considered as "confirmed" if composition, proposed properties, and database entry were a match.

(4) Identify products that are "likely" to contain nanomaterials: In cases where the ingredients of a product suggested that it might contain nanomaterials or the proposed properties would make it likely that the product contained nanomaterials, we used expert judgement to assess if the product was likely to contain nanomaterials. This included comparing the information about the product with similar nanomaterials described in the literature and what had been reported about the particle size distribution in such products.

(5) Check remaining products if assignment of the term "unlikely" to contain nanomaterials makes sense. For a product that did not declare any ingredients, we checked if this type of product usually contains nanomaterials. We also checked the promised properties and if they make the product more or less likely to contain nanomaterials. For example, cosmetics containing $\mathrm{TiO}_{2}$ that were stated to make the skin look whiter (white skin is a sign of beauty among Asian women) were considered to be "unlikely" because only non-nano $\mathrm{TiO}_{2}$ would have this effect.

\subsection{Determination of Emission of ENP into the Aquatic Environment}

ENP can be emitted into the aquatic environment during the use and the disposal of ENP-containing products. In order to determine which kind of ENP is most likely to reach the water systems, we identified release factors from previous studies [21-23], by evaluating published information on:

(a) The article's lifetime;

(b) The ways that ENP is incorporated in the products (i.e., suspended in liquid/solid, surface bound, or in the bulk);

(c) Release pattern (i.e., down the drain, runoff, and incineration and landfill).

The obtained information was then used to define the likelihood of ENP-containing consumer products releasing ENP into the aquatic environment.

The quantity of ENP released into the wastewater collection systems was estimated from the concentration of ENP in products ( $\%$ by weight), the release quantity of the products $\left(\mathrm{g} \cdot \mathrm{capita}^{-1} \cdot \mathrm{d}^{-1}\right)$, and its market share (\%). It was expressed in the form of a mass balance (Equation 1):

$$
M_{E N P_{i}}=C_{E N P_{i}} \cdot E_{\text {prod }_{i}} \cdot F_{\text {share }}
$$

where $M_{E N P_{i}}=$ daily amount of ENP $i$ released from a product into the aquatic environment, $\left(\mathrm{g} \cdot\right.$ capita $\left.^{-1} \cdot \mathrm{d}^{-1}\right) ; C_{E N P_{i}}=$ concentration of ENP in the product, $(\%$ by weight $) ; E_{\text {prod }_{i}}=$ daily per capita quantity of the product reaching the aquatic environment, $\left(\mathrm{g} \cdot \mathrm{capita}^{-1} \cdot \mathrm{d}^{-1}\right) ; F_{\text {share }}=$ market share of ENP-containing product, $(\%) ; C_{E N P_{i}}=$ ENP concentration. 
None of the investigated products contained information on ENP concentrations and none of the producers shared such information in a publicly available format. Thus, ENP concentration was estimated from the literature and from the allowable maximum level of ENP in a specific product according to the regulatory standards. If no information could be obtained for a specific product, the ENP concentration was extrapolated based on available information on ENP concentrations in the same or similar products. For example, the allowable maximum level of $\mathrm{TiO}_{2}$ in sunscreen is $25 \%$ according to EU regulations [24]. Based on this information, sunscreen containing another metal oxide as a UV blocking agent (e.g., $\mathrm{ZnO}$ ) was assumed to contain up to $25 \%$ of this UV-blocking agent.

\subsection{1. $E_{\text {prod }_{i}}$ Daily Release Quantity}

The daily release quantity was calculated from the average product amount used by consumers as described in the literature, and information about the aquatic environments into which they are likely to be released. The proportion of these quantities released into water was described with a "release factor." This factor was defined as the fraction of ENP released to the drain or urban runoff to the total amount used in each application. It was estimated from usage scenarios and anticipated release patterns. For example, some of the ENP contained in sunscreen may be released when people go swimming. In Singapore, swimming is possible only in pools and in the ocean. Most people have easy access to swimming pools either in their condominium or in nearby public sports centers, whereas for swimming in the ocean they have to travel to the coast. For the present study, $10 \%$ of ENP was assumed to be released into the sea while the other $90 \%$ was assumed to reach the wastewater stream through swimming pools, the shower, and washing of clothes soiled with sunscreen.

\subsection{2. $F_{\text {share }}$ Market Share}

The market share of ENP-containing consumer products was used for the estimation of the quantity of each ENP reaching different aquatic environments. The market share was estimated from the total number of brands identified in the stores and the number of products in each of the categories in Singapore's retail market assessed in this survey, and from published information about the global nanotechnology market [25].

Consumer products used for transportation purposes show a very different pattern. Thus, estimates of the quantity of ENP released from tires were determined by using published release factors per vehicle combined with driving distance and traffic statistics published by the Land Transportation Authority of Singapore [26,27].

\section{Results and Discussion}

\subsection{Types of ENP and Their Application in Consumer Products in the Singapore Retail Market}

In the first step, reports and literature [3,8,9,20,22,28-41], were reviewed to identify the most frequently used ENP and their applications. $\mathrm{Ag}, \mathrm{TiO}_{2}, \mathrm{Al} / \mathrm{Al}_{2} \mathrm{O}_{3}, \mathrm{ZnO}, \mathrm{SiO}_{2}$, ceramics, iron/iron oxide, carbon nanomaterials, and nanoclays were identified as the most frequently used ENP in consumer products. The identified ENP along with its function and consumer product application are summarized in Table 1. These identified uses of ENP types guided our nano-inventory activities. 
In our Singapore market inventory, we evaluated 1432 articles. Of these, 431 were "confirmed" (138 articles) or "likely" (293 articles) to contain ENP. The results are summarized in Table 2. These ENP-containing products occurred in nine different categories: (1) sunscreen, (2) cosmetics, (3) health and fitness, (4) automotive, (5) food, (6) home and garden, (7) clothing and footwear, (8) eyeglass/lens coating, and (9) electronics (see Figure 1). A total of 27 different types of nanomaterials were identified in these articles. In particular, ENP were widely utilized in the category of Food (175 articles), Health and fitness (108 articles), Cosmetics (68 articles), and Sunscreen (23 articles). Of

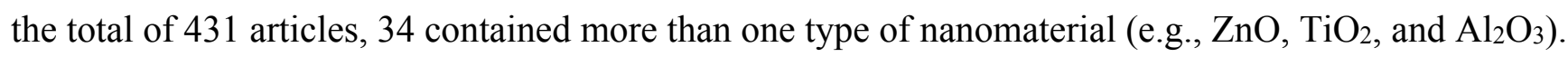
In our nano-inventory, it is relevant to note that housekeeping cleaning products supplied in the Singapore market such as laundry detergents or air fresheners have no detailed information regarding the products' ingredients. Thus, it was not possible to assess if these products contained ENP or not.

Table 1. Applications of ENP in identified consumer articles.

\begin{tabular}{|c|c|c|c|}
\hline ENMs & Function & Application Areas & Reference \\
\hline $\mathrm{Ag}$ & $\begin{array}{l}\text { Antimicrobial protection } \\
\text { Conductivity or electrical properties }\end{array}$ & $\begin{array}{l}\text { Textiles, food packaging, medical devices, } \\
\text { water treatment process, surface coating, } \\
\text { electronics such as transparent conducting } \\
\text { films, transparent electrodes for } \\
\text { flexible devices }\end{array}$ & {$[3,8,9,20,28-30]$} \\
\hline $\mathrm{TiO}_{2}$ & $\begin{array}{l}\text { Absorption of ultraviolet radiation } \\
\text { Catalyst }\end{array}$ & $\begin{array}{l}\text { Electronic devices, sunscreen, cleaning, water } \\
\text { treatment, solar cell, health and fitness }\end{array}$ & {$[8,9,20,28,29]$} \\
\hline $\mathrm{Al}_{2} \mathrm{O}_{3}$ & $\begin{array}{l}\text { Extremely fine powder with great } \\
\text { capability of polishing } \\
\text { Absorption of light } \\
\text { Antimicrobial protection } \\
\text { Adsorbent }\end{array}$ & $\begin{array}{l}\text { Cleaning, cosmetics, water treatment, coatings, } \\
\text { food additives, catalysts, ceramics, } \\
\text { electrical insulators }\end{array}$ & {$[8,9,20,28]$} \\
\hline $\mathrm{Al}$ & $\begin{array}{l}\text { Dispersion strength } \\
\text { catalyst }\end{array}$ & $\begin{array}{l}\text { Cosmetics, catalysts, coating, optical } \\
\text { biomaterials, drug delivery }\end{array}$ & {$[8,20,28,31]$} \\
\hline $\mathrm{ZnO}$ & $\begin{array}{l}\text { Sun protection } \\
\text { Antimicrobial protection }\end{array}$ & $\begin{array}{l}\text { Sunscreen, cleaning, paints, cosmetics, food } \\
\text { packaging, personal care products/sprays }\end{array}$ & {$[8,9,20,28]$} \\
\hline $\mathrm{SiO}_{2}$ & Extend life of paints and coatings & Paints, coatings, food packaging & {$[8,9,20,28]$} \\
\hline $\mathrm{Zr} / \mathrm{ZrO}_{2}$ & $\begin{array}{l}\text { Good absorbability and hydrophilicity } \\
\text { Bio-corrosion resistant and } \\
\text { bio-compatible }\end{array}$ & $\begin{array}{l}\text { Drug delivery, water treatment (membrane, ion } \\
\text { exchanger), coatings, fuel, battery, pigment, } \\
\text { abrasive material, medical implant }\end{array}$ & {$[8,28,32,33]$} \\
\hline Hydroxyapatite & Biocompatibility & $\begin{array}{l}\text { Therapeutic and/or diagnostic agents coatings, } \\
\text { drug delivery, sensor, biomaterials }\end{array}$ & {$[8,20,28,34-36]$} \\
\hline Ceramics & $\begin{array}{l}\text { Filtration with great rejection } \\
\text { efficiency } \\
\text { Hardness and strength }\end{array}$ & $\begin{array}{l}\text { Home and health/filter, paint, personal care } \\
\text { products, cosmetics, food and } \\
\text { beverage, coatings }\end{array}$ & {$[3,8,20,28]$} \\
\hline $\mathrm{CeO}_{2}$ & $\begin{array}{l}\text { Catalyst } \\
\text { Sun protection } \\
\text { Optical property }\end{array}$ & $\begin{array}{l}\text { Coatings, paints, automotive/fuel catalysts, } \\
\text { biomedicine }\end{array}$ & {$[8,28,37-39]$} \\
\hline
\end{tabular}


Table 1. Cont.

\begin{tabular}{|c|c|c|c|}
\hline ENMs & Function & Application Areas & Reference \\
\hline $\mathrm{Fe} / \mathrm{Fe}_{\mathrm{x}} \mathrm{O}_{\mathrm{y}}$ & $\begin{array}{l}\text { Hardness and strength } \\
\text { magnetic and catalytic properties }\end{array}$ & $\begin{array}{l}\text { Food and beverage, home and health/sporting } \\
\text { goods, environmental remediation, water } \\
\text { treatment, catalysts }\end{array}$ & {$[8,9,28,40]$} \\
\hline $\begin{array}{l}\text { Carbon nanomaterials } \\
\qquad\left(\mathrm{C}_{60} \text {, carbon black, }\right. \\
\text { carbon nanotubes }(\mathrm{CNT})\end{array}$ & $\begin{array}{l}\text { Hardness and strength } \\
\text { Light with high density } \\
\text { Conductivity } \\
\text { Metallic property } \\
\text { Mechanical and Magnetic property }\end{array}$ & $\begin{array}{l}\text { Probing electronic devices, catalysts, } \\
\text { adsorbent in water treatment, detection } \\
\text { devices, molecular filtration membrane, } \\
\text { detection sensor or probe, automotive, } \\
\text { sporting goods, clothing, food packaging }\end{array}$ & {$[3,8,9,20,22]$} \\
\hline Nanoclays & $\begin{array}{l}\text { Hardness and strength } \\
\text { Improvements in mechanical, } \\
\text { thermal, flame resistance, and } \\
\text { barrier properties }\end{array}$ & $\begin{array}{l}\text { Food packaging, automotive, cosmetics and } \\
\text { toiletries, environment and water treatment, } \\
\text { flame retardants, medical devices, packaging, } \\
\text { paints, pigments and coatings }\end{array}$ & {$[3,8,20,28]$} \\
\hline Organic nanomaterials & \multicolumn{2}{|c|}{$\begin{array}{l}\text { Organic nanomaterials are widely used in a variety of field, including vitamins, } \\
\text { anti-oxidants, color agents, flavors, preservatives, drug delivery, cosmetics, nutrients } \\
\text { and supplements. }\end{array}$} & {$[8,20,28]$} \\
\hline Other nanomaterials & \multicolumn{2}{|c|}{$\begin{array}{l}\text { Many other nanomaterials are being increasingly used in the commercial field, } \\
\text { including } \mathrm{Cu} \text { and } \mathrm{Cu}_{\mathrm{x}} \mathrm{O}_{\mathrm{y}}, \mathrm{Ti} \text {, metal nitrides, and alkaline earth metals. Quantum dots } \\
\text { composed of metal (oxide), or semiconductor materials with novel electronic, } \\
\text { optical, magnetic and catalytic properties are used in medical imaging, diagnostics } \\
\text { and security printing at increasing rates. }\end{array}$} & {$[3,8,20,28,41]$} \\
\hline
\end{tabular}

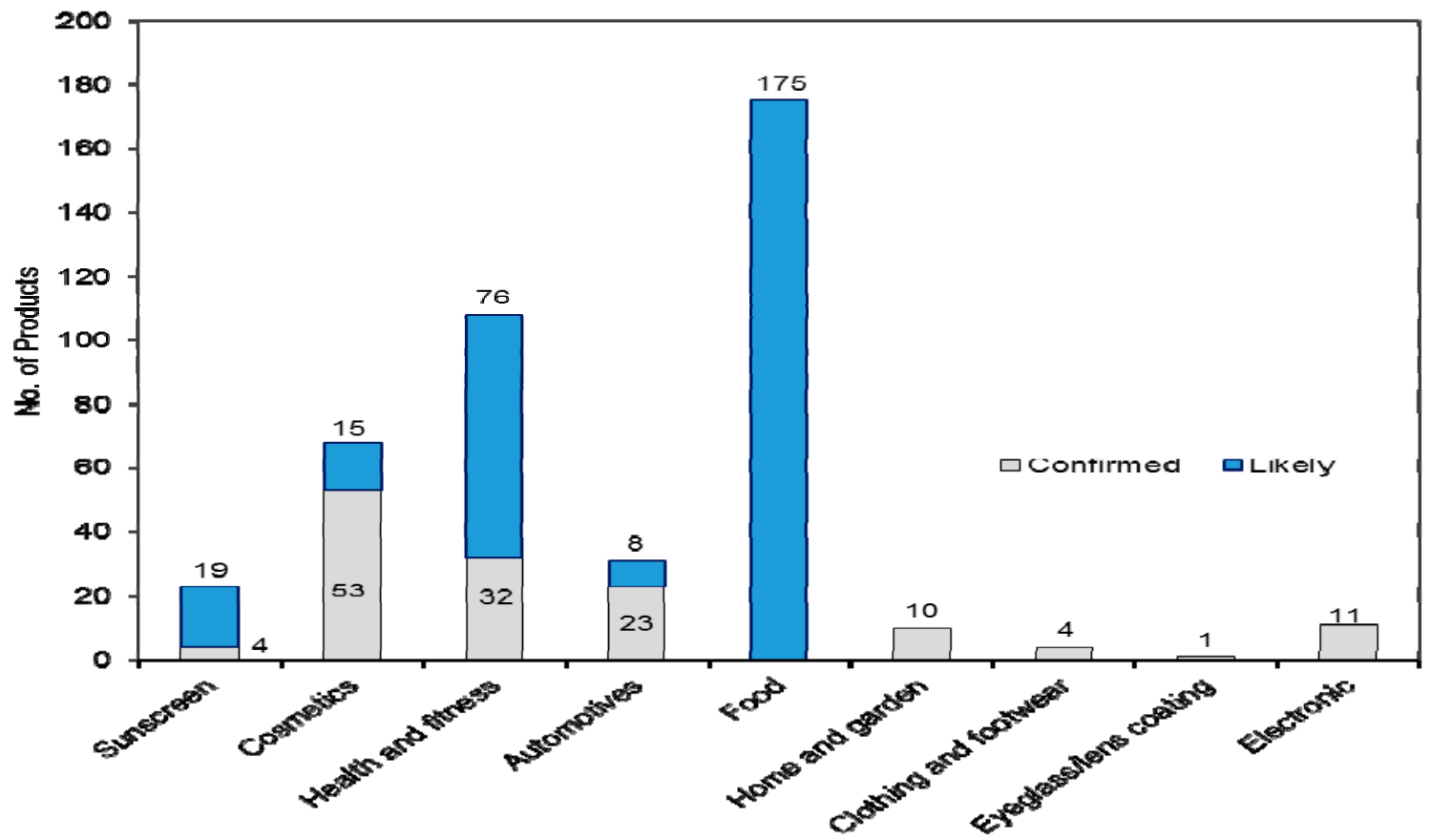

Figure 1. Distribution and category of products with confirmed or likely use of nanomaterials.

In the category of Health and fitness (or personal care products) and Food, $\mathrm{TiO}_{2}$ and $\mathrm{SiO}_{2}$ were widely used, namely in toothpastes, beverages, instant noodles, and sweets, either as a color additive or an anti-caking agent, respectively. The ingredients of the products had no indication if they were in the nanoscale or not. However, Weir et al., (2012) [42] reported that approximately 39\% of food-grade 
$\mathrm{TiO}_{2}$ particles counts were less than $100 \mathrm{~nm}$ in at least one dimension and that they readily dispersed into water as fairly stable colloids. Even though this report was limited because the percentage only referred to particles smaller than $220 \mathrm{~nm}$ (thus ignoring many of the larger, white $\mathrm{TiO}_{2}$ particles), it confirmed the presence of nanoparticles in food-grade $\mathrm{TiO}_{2}$. Peter et al., (2012) [43] observed the presence of nanosized $\mathrm{SiO}_{2}$ during the digestion of foods containing $\mathrm{SiO}_{2}$ as a food additive using SEM. Thus, for the purpose of this study, which aims to estimate ENP concentrations in different aquatic environments, toothpaste, beverages, instant noodles, and sweets were categorized as likely to contain ENP. Ag was used in many consumer products as an antibacterial agent, including: cleaning detergent products in the category of Home and garden (4), household electrical appliances (4) in Electronics, toothbrush (1) in Health and fitness (personal care), and socks (1) in Clothing and footwear.

Of the 431 articles with confirmed or likely use of ENP, producers declared the use of nanomaterials or nanotechnology for 69 of them, but no indication on the type of nanomaterials was provided. They were from the sectors of skincare/makeup/cosmetics (18), health and fitness (23), automotive (22), and clothing (6). Since it was not possible to directly determine the type of nanomaterial, they were not included in the modeling of emission quantity, which may lead to a slight underestimation of quantities.

Most of the commonly used nanomaterials listed in Table 1 were also identified in our inventory of the Singapore retail market. Some others, however, were not found, namely: $\mathrm{CeO}_{2}$, Quantum dots, $\mathrm{Zr} / \mathrm{ZrO}_{2}$, and Hydroxyapatite. This may be attributed to insufficient information about an article's ingredients, lack of penetration of those types of nanomaterials into the (Singapore) market, or the fact that these may be niche products not found in major retail and cosmetic stores.

\subsection{Release of ENP during Use and Disposal of Consumer Products}

The product types and the ENP contained therein were assessed with regard to their likely release patterns into the aquatic environment during the use or disposal of the articles. The various product categories were assigned to the following release paths:

Sunscreen, cosmetics: Both the review results and nano-inventory results indicate that the main ENP in this category includes $\mathrm{TiO}_{2}$ and $\mathrm{ZnO}$, which was expected because sunscreen use was likely to be significant in a tropical area such as Singapore. In this category, both $\mathrm{TiO}_{2}$ and $\mathrm{ZnO}$, are suspended in liquid. They can be directly released during the use and wash-off process. Most of them will be released into wastewater, while negligible amounts will go into surface water (no swimming in Singapore's fresh water reservoirs and lakes).

1. Health and fitness (personal care): $\mathrm{TiO}_{2}, \mathrm{SiO}_{2}$, metal oxides, and nano carbon are widely used in this category. Products include: toothpaste, shampoo, shower gel/milk, facial cleaning gel, and body lotion with UV protection. The use of products in this category will lead to direct release of ENP into the wastewater. For example, $\mathrm{TiO}_{2}$ can be easily released from toothpaste during tooth brushing. In addition, $\mathrm{SiO}_{2}$-containing facial cleaning gel and shampoo have great potential to release particulate $\mathrm{SiO}_{2}$ into wastewater.

2. Automotive (i.e., tire, polish and wax, coating, fuel additives): This category was found to be important primarily because of consumables such as tires, which are worn down during their lifetime. This can lead to direct release of ENP into the air and onto road surfaces, from where ENP can go directly into the aquatic environment via road runoff into surface water and in small 
quantities by air transport and dry deposition. ENP from maintenance products and accessories, such as car coatings or wax products, can be released into road runoff but also into wastewater during their application at private homes. The predominant ENP in this category include carbon black, ceramics, and $\mathrm{SiO}_{2}$.

3. Home and garden (e.g., coatings, cleaning products): $\mathrm{TiO}_{2}, \mathrm{Ti}$, and $\mathrm{Ag}$ are widely used in this category. Products in this category are relevant in terms of potential for direct release of ENP into surface water by outdoor use, and into wastewater during indoor use and disposal of products.

4. Clothing and footwear: Ag is used in nano form in textiles as an antimicrobial agent. Wearing clothing with $\mathrm{Ag}$ is expected to lead to only minimal direct release of $\mathrm{Ag}$ into the aquatic environment. The main release will occur during washing of clothing containing nanoparticles of $\mathrm{Ag}$ into the wastewater systems [44]. The amount of ionic and particulate Ag released from the fabrics depends on the type of $\mathrm{Ag}$ incorporation into the textile.

5. Eyeglass/lens coating: This is a small-scale use category. ENP may be released into wastewater when washing glasses but only if the ENP were non-permanently coated on the surface of the lenses. The main ENP involved include $\mathrm{TiO}_{2}, \mathrm{SiO}_{2}$, and polymer thin films, which are all permanent coatings.

6. Construction materials, paint, and coating: Most nanomaterials being used in this category are fixed in the products. Some ENP such as Ag will be released in ionic form. Environmental degradation over time and rainfall flushing during heavy storms may cause small quantities of ENP to be released into the aquatic environment. Most of the released nanosized particles are expected to go into surface runoff.

For each of the 431 articles confirmed or likely to contain nanoparticles, the likelihood of releasing ENP into the aquatic environments was assessed based on the above considerations. Of the 431 products assessed, $324(75 \%)$ were identified as likely to release ENP into the aquatic environment and 107 (25\%) were unlikely. Table 3 shows the types of matrices that contain ENP in the identified products, the expected release pattern, and the assigned release factor into the aquatic environments. The "release factor" is defined as the fraction of ENP released "down the drain" compared to the total usage quantity. The value of these release factors were identified in the literature and estimated for the purpose of this study. Assumptions behind estimates are listed in the reference column. For example, as women may use facial cottons to remove makeup products such as foundation cream and concealer before face washing, the assumption was made that $70 \%$ of the substance was transferred via the facial cottons into solid waste. The remaining $30 \%$ will then reach the drain during face washing. In some cases, the value of the release factor was set to $0 \%$, which means these products are not likely to release ENP into the aquatic environment despite the presence of a hypothetical release pathway. For example, nano-capsules and nano-hyaluronic acid in skincare products can be adsorbed when they come into contact with skin. After adsorption, they will lose their nano form and thus the release factor for these skincare products was assumed to be $0 \%$. Also products such as rackets and toothbrushes which have a permanent coating would not release ENP through their lifetime. $\mathrm{TiO}_{2}$ and $\mathrm{SiO}_{2}$ contained in beverages, snacks, instant noodles, and sweets were assumed to enter into the aquatic environment after passing through the gastrointestinal tract, whereas food that was thrown away would land in solid waste treatment and thus not enter the aquatic system. 
Table 2. Product category vs. ENP within 431 products assessed.

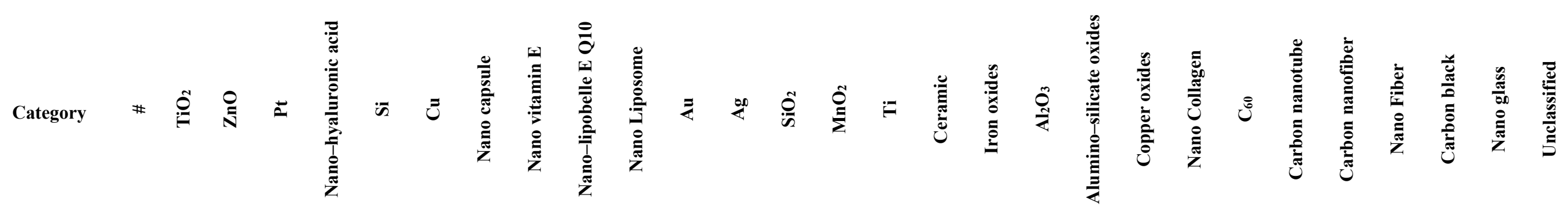

\begin{tabular}{|c|c|c|c|c|c|c|c|c|c|c|c|c|c|c|c|c|c|c|c|c|c|c|c|c|c|c|c|c|c|}
\hline Sunscreen & 23 & 19 & 12 & & & & & & & & & & & & & & & & & & & & & & & & & & \\
\hline Cosmetics & 68 & 22 & 2 & 5 & 4 & 1 & 1 & 2 & 1 & 2 & 1 & 12 & & 1 & 1 & & & 4 & 4 & 1 & 1 & 2 & & & & 1 & & & 19 \\
\hline $\begin{array}{l}\text { Health and } \\
\text { fitness }\end{array}$ & $\begin{array}{c}10 \\
8\end{array}$ & 69 & 1 & & & & & & & & & 1 & 1 & 18 & & 2 & & 1 & & & & & 1 & 1 & 1 & 2 & & & 22 \\
\hline Automotive & 31 & 1 & & & & & & & & & & & & 1 & & & 5 & & & & & & & & & & 1 & 1 & 22 \\
\hline Food & $\begin{array}{c}17 \\
5\end{array}$ & 11 & 5 & & & & & & & & & & & 159 & & & & & & & & & & & & & & & \\
\hline $\begin{array}{l}\text { Home and } \\
\text { garden }\end{array}$ & 10 & 6 & & & & & & & & & & & 4 & & & 1 & & & & & & & & & & & & & \\
\hline Clothing & & & & & & & & & & & & & & & & & & & & & & & & & & & & & \\
\hline $\begin{array}{c}\text { and } \\
\text { footwear }\end{array}$ & 4 & & & & & & & & & & & & 1 & & & & & & & & & & & & & & & & 3 \\
\hline Eyeglass/ & & & & & & & & & & & & & & & & & & & & & & & & & & & & & \\
\hline $\begin{array}{l}\text { lens } \\
\text { coatings }\end{array}$ & 1 & & & & & & & & & & & & & & & & & & & & & & & & & & & & 1 \\
\hline Electronics & 11 & & & & & & & & & & & & 4 & & & 4 & 1 & & & & & & & & & & & & 2 \\
\hline Total & $\begin{array}{c}43 \\
1 \\
\end{array}$ & $\begin{array}{c}12 \\
8 \\
\end{array}$ & 20 & 6 & 4 & 1 & 1 & 2 & 1 & 2 & 1 & 13 & 10 & 179 & 1 & 7 & 6 & 5 & 4 & 1 & 1 & 2 & 1 & 1 & 1 & 2 & 1 & 1 & 69 \\
\hline
\end{tabular}


Table 3. The type of matrix containing ENP, release pattern and release factor for different products.

\begin{tabular}{|c|c|c|c|c|c|c|}
\hline Product & Category & ENP Type & $\begin{array}{l}\text { Type of Matrix } \\
\text { Containing ENP }\end{array}$ & $\begin{array}{l}\text { Release } \\
\text { Pattern }\end{array}$ & $\begin{array}{c}\text { Release } \\
\text { Factor }(\%) \\
\end{array}$ & Reference \\
\hline Sunscreen & Sunscreen & $\mathrm{TiO}_{2}, \mathrm{ZnO}$ & Suspended in liquid & $\begin{array}{l}\text { Down the } \\
\text { drain }\end{array}$ & 90 & $\begin{array}{l}\text { Only } 0.03 \% \text { ENP can penetrate into } \\
\text { skin after } 24 \mathrm{~h} \text { exposure [45] and } 10 \% \\
\text { loss in the sea }\end{array}$ \\
\hline Day cream & Skincare/Cosmetics & $\mathrm{Pt}$ & Suspended in liquid & $\begin{array}{l}\text { Down the } \\
\text { drain }\end{array}$ & 95 & $\begin{array}{l}\text { Assumption: approximately } 5 \% \text { losses } \\
\text { to solid waste and other solid phases. }\end{array}$ \\
\hline $\begin{array}{l}\text { Facial } \\
\text { cleaning gel }\end{array}$ & Skincare/Cosmetics & Nano-hyaluronic acid & Suspended in liquid & - & 0 & $\begin{array}{l}\text { Based on the assumption: present in } \\
\text { form of small vesicles that get } \\
\text { approximately } 100 \% \text { adsorbed on the } \\
\text { skin and loose nano form. }\end{array}$ \\
\hline $\begin{array}{c}\text { Facial } \\
\text { cleaning gel }\end{array}$ & Skincare/Cosmetics & $\mathrm{MnO}_{2}$ & Suspended in liquid & $\begin{array}{l}\text { Down the } \\
\text { drain }\end{array}$ & 100 & $\begin{array}{l}\text { Technical guide document on risk } \\
\text { assessment, } 2003[46]\end{array}$ \\
\hline Day cream & Skincare/Cosmetics & $\mathrm{Au}, \mathrm{TiO}_{2}$ & Suspended in liquid & $\begin{array}{l}\text { Down the } \\
\text { drain }\end{array}$ & 95 & $\begin{array}{l}\text { Assumption: approximately } 5 \% \text { loss to } \\
\text { solid waste and other solid phases. }\end{array}$ \\
\hline Mask cream & Skincare/Cosmetics & $\mathrm{Pt}$ & Suspended in liquid & $\begin{array}{l}\text { Down the } \\
\text { drain }\end{array}$ & 95 & $\begin{array}{l}\text { Based on the assumption: } \\
\text { approximately } 5 \% \text { loss to solid waste } \\
\text { and other solid phases. }\end{array}$ \\
\hline Day cream & Skincare/Cosmetics & Nano-capsules & Suspended in liquid & - & 0 & $\begin{array}{l}\text { Nano-capsules were described to be } \\
\text { adsorbed completely by } \\
\text { Lademann et al., } 2013 \text { [47]. }\end{array}$ \\
\hline Eyeliner & Makeup/Cosmetics & Iron oxides & Suspended in solid & $\begin{array}{l}\text { Down the } \\
\text { drain }\end{array}$ & 10 & $\begin{array}{l}90 \% \text { of the product retention on the } \\
\text { facial cotton }\end{array}$ \\
\hline Concealer & Makeup/Cosmetics & $\mathrm{Al}_{2} \mathrm{O}_{3}$ & Suspended in liquid & $\begin{array}{c}\text { Down the } \\
\text { drain }\end{array}$ & 30 & $70 \%$ retention on the facial cotton \\
\hline
\end{tabular}


Table 3. Cont.

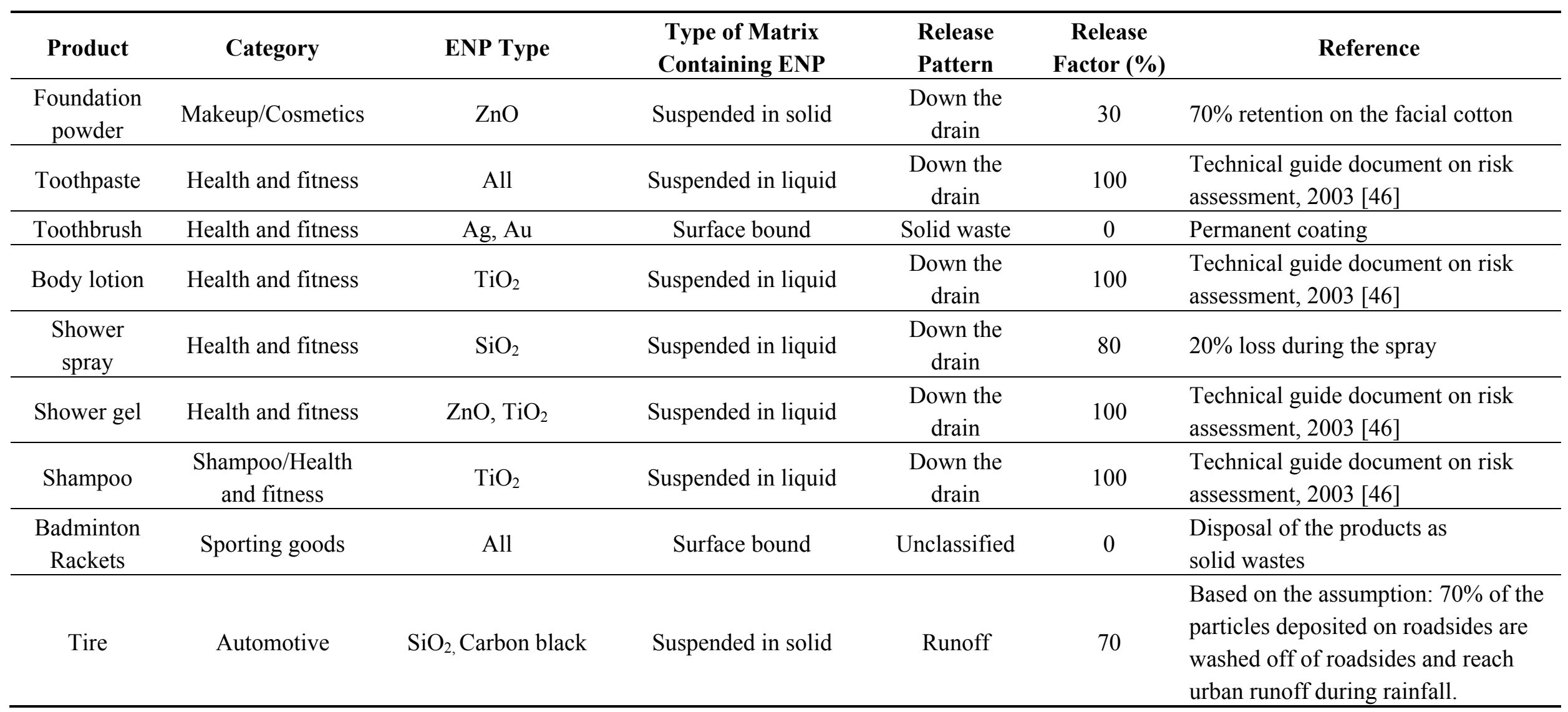


Table 3. Cont.

\begin{tabular}{|c|c|c|c|c|c|c|}
\hline Product & Category & ENP Type & $\begin{array}{l}\text { Type of Matrix } \\
\text { Containing ENP }\end{array}$ & $\begin{array}{l}\text { Release } \\
\text { Pattern }\end{array}$ & $\begin{array}{c}\text { Release } \\
\text { Factor }(\%)\end{array}$ & Reference \\
\hline $\begin{array}{l}\text { Car coating } \\
\text { ( } \& \text { polish } \\
\text { wax) }\end{array}$ & Automotive & Ceramic, $\mathrm{TiO}_{2}$ & Suspended in liquid & $\begin{array}{l}\text { Down the } \\
\text { drain }\end{array}$ & 100 & Kojima et al., 2011 [48] \\
\hline $\begin{array}{l}\text { Beverages, } \\
\text { instant } \\
\text { noodles, } \\
\text { seasoning, } \\
\text { snacks, } \\
\text { sweets }\end{array}$ & Food & $\mathrm{TiO}_{2}, \mathrm{SiO}_{2}$ & Suspended in solid & $\begin{array}{l}\text { Down the } \\
\text { drain }\end{array}$ & 60 & $\begin{array}{l}\text { Oral exposure is assumed to be the } \\
\text { main route in terms of Food. } \mathrm{SiO}_{2} \\
\text { and } \mathrm{TiO}_{2} \text { are assumed to not dissolve } \\
\text { during passage through the } \\
\text { gastrointestinal tract. However, } \\
\text { according to UNEP } 2011,30 \% \text { of } \\
\text { food gets thrown away [49]. } \\
\text { Long-term retention in the body is } \\
\text { not clear, but assumed to be } 10 \% \text {. }\end{array}$ \\
\hline Beverage & Food & $\mathrm{ZnO}$ & Suspended in solid & - (as ions) & 0 & $\begin{array}{l}\text { Oral exposure is assumed to be the } \\
\text { main route in terms of Food. } \mathrm{ZnO} \text { is } \\
\text { assumed to be transferred into ionic } \\
\text { form during passage through the } \\
\text { gastrointestinal tract. }\end{array}$ \\
\hline $\begin{array}{l}\text { Cleaning } \\
\text { detergent }\end{array}$ & Home and garden & $\mathrm{TiO}_{2}, \mathrm{Ag}, \mathrm{Ti}$ & Suspended in liquid & $\begin{array}{l}\text { Down the } \\
\text { drain }\end{array}$ & 100 & $\begin{array}{l}\text { Technical guide document on risk } \\
\text { assessment, } 2003 \text { [46] }\end{array}$ \\
\hline Filter & Home and garden & $\mathrm{Ag}$ & Surface bound & Unclassified & 0 & Permanent coating \\
\hline Socks & Clothing and footwear & $\mathrm{Ag}$ & Surface bound & $\begin{array}{l}\text { Down the } \\
\text { drain }\end{array}$ & 100 & $\begin{array}{l}\text { Technical guide document on risk } \\
\text { assessment, } 2003 \text { [46] }\end{array}$ \\
\hline $\begin{array}{c}\text { Hair } \\
\text { curling } \\
\text { machine }\end{array}$ & $\begin{array}{c}\text { Household } \\
\text { appliances/Electronics }\end{array}$ & $\mathrm{Ag}, \mathrm{Ti}$, and ceramic & Surface bound & - & 0 & Permanent coating \\
\hline $\begin{array}{l}\text { Washing } \\
\text { machine }\end{array}$ & $\begin{array}{c}\text { Household } \\
\text { appliances/Electronics }\end{array}$ & $\mathrm{Ag}$ & Surface bound & $\begin{array}{l}\text { Down the } \\
\text { drain }\end{array}$ & 100 & Tiede et al., 2011 [50] \\
\hline
\end{tabular}




\subsection{Estimation of ENP Reaching the Aquatic Environment}

The amount of ENP reaching the aquatic environment was determined from the concentration of ENP in the products containing them, the daily release quantity of this product type to the aquatic environment, and the market share of the products containing ENP.

ENP concentrations in products. The concentration of ENP in different products was estimated from the literature and relevant regulatory standards. Table 4 shows ENP concentrations for different products. Their values were found to vary to some extent among different products of the same category, as shown in Figure 2 for $\mathrm{TiO}_{2}, \mathrm{SiO}_{2}, \mathrm{ZnO}$, and $\mathrm{Ag}$. The difference in ENP concentrations is attributed to the different function of ENP in different products.
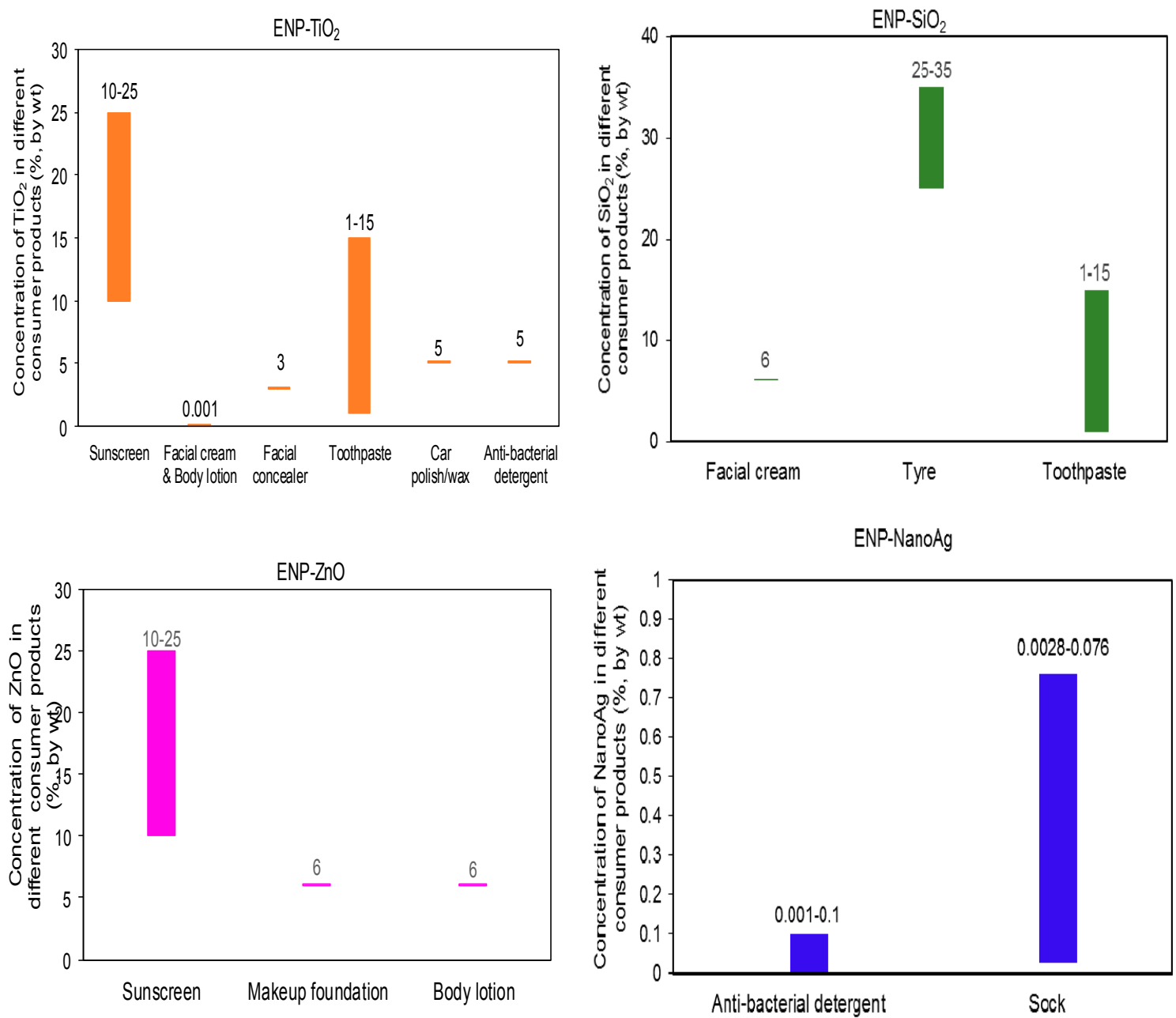

Figure 2. Concentration ranges of nano-scale $\mathrm{TiO}_{2}, \mathrm{SiO}_{2}, \mathrm{ZnO}$, and $\mathrm{Ag}$ in different consumer product categories (see also Table 4). 
Table 4. Concentrations of nanomaterials in different consumer products.

\begin{tabular}{|c|c|c|c|c|}
\hline \multirow[t]{2}{*}{ Category } & \multirow[t]{2}{*}{ ENP Type } & \multicolumn{2}{|c|}{$\begin{array}{c}\text { ENP Concentration } \\
\text { (\% by Weight })\end{array}$} & \multirow[t]{2}{*}{ References } \\
\hline & & Low & High & \\
\hline Sunscreen & $\mathrm{TiO}_{2}$ & 10 & 25 & $\begin{array}{l}\text { Weir et al., } 2012 \text { [42], EC regulation on } \\
\text { Sunscreen [24] }\end{array}$ \\
\hline Sunscreen & $\mathrm{ZnO}$ & 10 & 25 & $\begin{array}{l}\text { Weir et al., } 2012 \text { [42], EC regulation on } \\
\text { Sunscreen [24] }\end{array}$ \\
\hline Day cream/Cosmetics & $\mathrm{Pt}$ & 10 & 20 & $\begin{array}{l}\text { Purest colloids: } \\
\text { http://www.purestcolloids.com/ } \\
\text { colloidal-skin-conditioners.php [51] }\end{array}$ \\
\hline Day cream/Cosmetics & Nano-lipobelle EQ10 & 0.5 & 4 & Müller et al., 2007 [52] \\
\hline Lotion/Cosmetics & Nano hyaluronic acid & 60 & 100 & $\begin{array}{l}\text { Based on the similar product information: } \\
\text { http://www.ebay.com.au/bhp/ } \\
\text { hyaluronic-acid-serum [53] }\end{array}$ \\
\hline Cream/Cosmetics & Nano-capsules & 0.5 & 4 & Müller et al., 2007 [52] \\
\hline Cream/Cosmetics & $\mathrm{Au}$ & 20 & 20 & Taufikurohmah et al., 2011 [54] \\
\hline Cream/Cosmetics & $\mathrm{SiO}_{2}$ & 6 & 15 & Tiede et al., 2011 [55] \\
\hline Facial cleaning gel/Cosmetics & $\mathrm{MnO}_{2}$ & 0.001 & 0.001 & Weir et al., 2012 [42] \\
\hline Facial cleaning gel/Cosmetics & $\mathrm{TiO}_{2}$ & 0.001 & 0.001 & Weir et al., 2012 [42] \\
\hline Foundation/Cosmetic & $\mathrm{TiO}_{2}$ & 0.5 & 4 & Müller et al., 2007 [52] \\
\hline Eyeliner/Cosmetic & Iron oxides & 3 & 3 & Tiede et al., 2011 [55] \\
\hline Eyeliner/Cosmetic & Nano Collagen & 0.5 & 4 & Müller et al., 2007 [52] \\
\hline Concealer/Cosmetic & $\mathrm{Al}_{2} \mathrm{O}_{3}$ & 3 & 3 & Tiede et al., 2011 [55] \\
\hline Foundation/Cosmetic & $\begin{array}{l}\text { Alumino-silicate } \\
\text { oxides }\end{array}$ & 3 & 3 & Tiede et al., 2011 [55] \\
\hline Eye shadow/Cosmetic & $\mathrm{Au}$ & 3 & 3 & Tiede et al., 2011 [55] \\
\hline Foundation/Cosmetic & $\mathrm{ZnO}$ & 3 & 3 & Tiede et al., 2011 [55] \\
\hline Toothpaste/Health and fitness & $\mathrm{TiO}_{2}$ & 1 & 15 & Weir et al., 2012 [42], Tiede et al., 2011 [55] \\
\hline Toothpaste/Health and fitness & $\mathrm{SiO}_{2}$ & 1 & 15 & Weir et al., 2012 [42], Tiede et al., 2011 [55] \\
\hline Toothbrush/Health and fitness & $\mathrm{Ag}$ & 0.001 & 0.1 & Weir et al., 2012 [42], Tiede et al., 2011 [55] \\
\hline Toothbrush/Health and fitness & $\mathrm{Au}$ & 0.001 & 0.1 & Weir et al., 2012 [42], Tiede et al., 2011 [55] \\
\hline Body lotion/Health and fitness & $\mathrm{TiO}_{2}$ & 0.001 & 0.001 & Weir et al., 2012 [42] \\
\hline $\begin{array}{c}\text { Shower spray/Health and } \\
\text { fitness }\end{array}$ & $\mathrm{SiO}_{2}$ & 0.001 & 0.001 & Weir et al., 2012 [42] \\
\hline Shampoo/Health and fitness & $\mathrm{TiO}_{2}$ & 0.001 & 0.001 & Weir et al., 2012 [42] \\
\hline Tire/Automotive & $\mathrm{SiO}_{2}$ & 25 & 35 & Wik et al., 2005 [56] \\
\hline Tire/Automotive & Carbon black & 25 & 35 & Wik et al., 2005 [56] \\
\hline Coating/Automotive & Ceramic & 10 & 10 & Boxall et al., 2007 [11] \\
\hline Coating/Automotive & Nano glass & 10 & 10 & Boxall et al., 2007 [11] \\
\hline Coating/Automotive & $\mathrm{TiO}_{2}$ & 5 & 5 & Boxall et al., 2007 [11] \\
\hline
\end{tabular}


Table 4. Cont.

\begin{tabular}{|c|c|c|c|c|}
\hline \multirow[t]{2}{*}{ Category } & \multirow[t]{2}{*}{ ENP Type } & \multicolumn{2}{|c|}{$\begin{array}{l}\text { ENP Concentration } \\
\text { (\% by Weight) } \\
\end{array}$} & \multirow[t]{2}{*}{ References } \\
\hline & & Low & High & \\
\hline Beverage/Food & $\mathrm{SiO}_{2}$ & 0 & $<1.5$ & $\begin{array}{l}\text { Health Canada: http://www.hc-sc.gc.ca/ } \\
\text { fn-an/securit/addit/list/1-anti-eng.php [57] }\end{array}$ \\
\hline Beverage/Food & $\mathrm{ZnO}$ & & $<1.5$ & $\begin{array}{l}\text { Health Canada: http://www.hc-sc.gc.ca/ } \\
\text { fn-an/securit/addit/list/1-anti-eng.php [57] }\end{array}$ \\
\hline Beverage/Food & $\mathrm{TiO}_{2}$ & & $<1.5$ & $\begin{array}{l}\text { Health Canada: http://www.hc-sc.gc.ca/ } \\
\text { fn-an/securit/addit/list/1-anti-eng.php [57] }\end{array}$ \\
\hline Instant noodle/Food & $\mathrm{SiO}_{2}$ & 1 & 1 & $\begin{array}{l}\text { Health Canada: http://www.hc-sc.gc.ca/ } \\
\text { fn-an/securit/addit/list/1-anti-eng.php [57] }\end{array}$ \\
\hline Sweets/Food & $\mathrm{TiO}_{2}$ & 0.34 & 0.34 & European food safety authority, 2004_[58]. \\
\hline Snack/Food & $\mathrm{SiO}_{2}$ & 1 & 1 & $\begin{array}{l}\text { Health Canada: http://www.hc-sc.gc.ca/ } \\
\text { fn-an/securit/addit/list/1-anti-eng.php [57] }\end{array}$ \\
\hline Seasoning/Food & $\mathrm{SiO}_{2}$ & 1 & 1 & $\begin{array}{l}\text { Health Canada: http://www.hc-sc.gc.ca/ } \\
\text { fn-an/securit/addit/list/1-anti-eng.php [57] }\end{array}$ \\
\hline Cleaning/Home and garden & $\mathrm{TiO}_{2}$ & 5 & 5 & Boxall et al., 2007 [11] \\
\hline Cleaning/Home and garden & $\mathrm{Ag}$ & 0.001 & 0.1 & Boxall et al., 2007 [11] \\
\hline Cleaning/Home and garden & $\mathrm{Ti}$ & 5 & 5 & Boxall et al., 2007 [11] \\
\hline $\begin{array}{l}\text { Antimicrobial coating/Home } \\
\text { and garden }\end{array}$ & $\mathrm{TiO}_{2}$ & 5 & 5 & Boxall et al., 2007 [11] \\
\hline Clothing and footwear & $\mathrm{Ag}$ & 0.0028 & 0.076 & Benn and Westerhoff, 2008 [44] \\
\hline $\begin{array}{l}\text { Household electrical } \\
\text { appliances/Electronics }\end{array}$ & $\mathrm{Ag}$ & 100 & 100 & Tiede et al., 2011 [55] \\
\hline
\end{tabular}

In some product categories, several different types of ENP may be used. For example, some manufacturers only added either $\mathrm{TiO}_{2}$ or $\mathrm{ZnO}$ (up to 25\%) to their sunscreen, while others used both. To estimate the individual ENP concentrations, $\mathrm{TiO}_{2}$ and $\mathrm{ZnO}$ were assumed to contribute equally to the total of $25 \% \mathrm{w} / \mathrm{w}$ contents. This approach was used for all categories, in which an article contained several types of ENP with similar functionality.

Daily release quantity. The usage quantity of ENP-containing consumer products was estimated from surveys of personal care products consumption in other countries. Biesterbos et al., (2013) [59] conducted a survey covering every province of the Netherlands. Both females and males were surveyed about usage patterns of personal care products in the past year. A wide range of personal care products were included, such as general hygiene, hair care, skin care, cosmetics (skincare products and makeup), and sunscreen. The collected data were used to determine the daily usage of these personal care products. While the study provided useful average usage data, no information was given about data variation such as standard deviation, range, or percentiles. Hall et al., (2007) [60] conducted a Europe-wide survey that focused on cosmetics but without breaking down the respondents by age. Loretz et al., (2008, 2006, and 2005) [50,61,62] did a survey to investigate the usage of cosmetics and personal care products over two weeks among females in the USA.

The literature review provided useful information but also indicated that the usage quantity for the same product can differ considerably between countries. For example, the per capita (pc) daily usage 
quantity range for body lotion was $0.4-21.4(\mathrm{~g} / \mathrm{pc} / \mathrm{d})$ in the Netherlands [59], 1.84-7.25 (g/pc/d) in Europa [60], and 3.8-13.8 $(\mathrm{g} / \mathrm{pc} / \mathrm{d})$ in the USA [61]. The difference on the usage quantity among different countries may be attributed to variations in the survey, such as respondents' age, ethnic group, body shape and gender, individual habits, and weather. To determine the usage quantity for food and beverages in Singapore, we selected data to be as representative as possible for Singapore, as detailed in Table 5. In addition to the abovementioned references, the Technical Guidance Document on Risk Assessment [46], a survey in the Exposure Factors Handbook [63], and the approach used in the UK to estimate nanomaterials' release into water [55] were also used to collate data on the usage pattern of car coatings/polish, food consumption, cleaning products, and clothing. Table 5 summarizes the usage quantity for each article.

Table 5. Summary of daily per capita usage quantity for different products.

\begin{tabular}{|c|c|c|c|c|}
\hline \multirow{2}{*}{ Product Name } & \multirow{2}{*}{ Category } & \multicolumn{3}{|c|}{ Usage Quantity (g/pc/d) } \\
\hline & & Low & High & References \\
\hline Sunscreen & Sunscreen & 0.04 & 1.90 & Biesterbos et al., 2013 [59] \\
\hline Day cream & Skincare/Cosmetics & 0.1 & 1.1 & Biesterbos et al., 2013 [59] \\
\hline Eye cream & Skincare/Cosmetics & 0.005 & 0.055 & Assumption: $1 / 20$ of the day cream. \\
\hline Toner & Skincare/Cosmetics & 0.5 & 4.3 & Biesterbos et al., 2013 [59] \\
\hline Night cream & Skincare/Cosmetics & 0.09 & 0.9 & Biesterbos et al., 2013 [59] \\
\hline Facial cleaning gel & Skincare/Cosmetics & 0.5 & 4.3 & Biesterbos et al., 2013 [59] \\
\hline Cream mask & Skincare/Cosmetics & 0.3 & 3.3 & $\begin{array}{l}\text { Assumption: } 3 \text { times more than } \\
\text { day cream }\end{array}$ \\
\hline Foundation & Makeup/Cosmetics & 0.002 & 0.132 & Loretz et al., $2006[50]$ \\
\hline Foundation powder & Makeup/Cosmetics & 0.002 & 0.132 & Loretz et al., 2006 [50] \\
\hline Eyeliner & Makeup/Cosmetics & 0.0002 & 0.0003 & Biesterbos et al., 2013 [59] \\
\hline Concealer & Makeup/Cosmetics & 0.006 & 0.06 & $\begin{array}{l}\text { Assumption: } 10 \% \text { of the usage quantity } \\
\text { of the foundation. }\end{array}$ \\
\hline Eye shadow & Makeup/Cosmetics & 0.006 & 0.06 & $\begin{array}{l}\text { Assumption: } 10 \% \text { of the usage quantity } \\
\text { of the foundation. }\end{array}$ \\
\hline Toothpaste & $\begin{array}{c}\text { Toothpaste/Health and } \\
\text { fitness }\end{array}$ & 1.515 & 2.669 & Hall et al., 2007 [60] \\
\hline Shampoo & Health and fitness & 3.79 & 21.91 & Loretz et al., 2006 [50] \\
\hline Body lotion & Health and fitness & 1.836 & 7.25 & Hall et al., 2007 [60] \\
\hline Shower gel & Health and fitness & 6 & 23 & Loretz et al., 2006 [50] \\
\hline Tire & Automotive & $\begin{array}{c}0.120 \\
\text { (unit: } \mathrm{g} / \mathrm{km} \text { ) }\end{array}$ & 0.120 & Gehrig et al., 2005 [64] \\
\hline Coating & Automotive & 0.3 & 0.3 & Tiede et al., 2011 [55] \\
\hline Instant coffee & Beverage/Food & 1.0 & 1.0 & $\begin{array}{l}\text { Derived from annual instant coffee } \\
\text { consumption of } 2000 \text { tons in } \\
\text { Singapore [65] }\end{array}$ \\
\hline
\end{tabular}


Table 5. Cont.

\begin{tabular}{|c|c|c|c|c|}
\hline \multirow{2}{*}{ Product Name } & \multirow{2}{*}{ Category } & \multicolumn{3}{|c|}{ Usage Quantity (g/pc/d) } \\
\hline & & Low & High & References \\
\hline Instant noodles & Food & 3.6 & 3.6 & $\begin{array}{l}\text { Seasoning powder }(15 \mathrm{~g}) \text { is } 14 \% \text { of an } \\
\text { instant noodle package weight }(110 \mathrm{~g}) \text {. } \\
\text { Daily intake of grain products is } 3.7 \\
\mathrm{~g} / \mathrm{kg} \text {-day, cited from } 2011 \text { Exposure } \\
\text { Factors Handbook of the USEPA [ } 63] \text {. } \\
\text { The range of BMI for Asians is } 17-35 \\
\mathrm{~kg} / \mathrm{m}^{2} \text { (WHO expert consultation report, } \\
2004 \text { ) [66]. The average height for male } \\
\text { and female in Singapore is } 1.7 \text { and } 1.6 \\
\text { meters, respectively [67]. Therefore, the } \\
\text { estimated average body weight for Asians } \\
\text { is assumed to be } 70 \mathrm{~kg} \text {. The percentage of } \\
\text { instant noodles in total grain products is } \\
\text { assumed to be } 10 \% \text {. Therefore, daily } \\
\text { intake of instant noodles is } \\
14 \% \times 259 \times 10 \%=3.6 \mathrm{~g} \text {. }\end{array}$ \\
\hline Seasoning powder & Food & 0.032 & 0.032 & Carlsen et al., 2011 [68] \\
\hline Snacks (Chips) & Food & 0.42 & 0.98 & $\begin{array}{l}\text { Daily intake of snacks for Asians is } \\
0.1( \pm 0.04) \mathrm{g} / \mathrm{kg} \text {-day (USEPA, 2011, } \\
\text { Exposure factors handbook) [63]. } \\
\text { The estimated average body weight for } \\
\text { Asians is assumed to be } 70 \mathrm{~kg} \text {. The } \\
\text { percentage of chips in total snacks is } \\
\text { assumed to be } 10 \% \text {. Daily intake of chips } \\
\text { is }=7( \pm 2.8) \times 10 \%=0.7( \pm 0.28) \mathrm{g} \text {. }\end{array}$ \\
\hline $\begin{array}{l}\text { Sweets } \\
\text { (Chocolate candy) }\end{array}$ & Food & 0.14 & 0.14 & $\begin{array}{l}\text { Daily per capita intake of sweets is } \\
0.4 \mathrm{~g} / \mathrm{kg} \text {-day in Exposure Factors } \\
\text { Handbook [63]. The estimated average } \\
\text { body weight for Asians is assumed to } \\
\text { be } 70 \mathrm{~kg} \text {. The percentage of chocolate } \\
\text { candy investigated in our inventory in } \\
\text { total sweets is assumed to be } 5 \% \text {. } \\
\text { Individual daily intake of chocolate } \\
\text { candy is } 0.4 \times 70 \times 5 \%=0.14 \mathrm{~g} \text {. }\end{array}$ \\
\hline Cleaning & Home and garden & 110 & 110 & $\begin{array}{l}\text { Technical guide document on risk } \\
\text { assessment, } 2003 \text { [46] }\end{array}$ \\
\hline Clothing & Clothing and footwear & 4.45 & 4.45 & $\begin{array}{l}\text { Assumption: } 1 / 20 \text { of emission from } \\
\text { clothing. Tiede } \text { et al., } 2011 \text { [55] }\end{array}$ \\
\hline Washing machine & $\begin{array}{l}\text { Household electrical } \\
\text { appliances }\end{array}$ & 1.375 & 1.375 & Tiede et al., 2011 [55] \\
\hline
\end{tabular}

Market share. The market share for each product category was estimated from our market survey and from published data, as shown in Table 6. 
Table 6. Estimated market share of ENP-containing consumer products in the Singapore retail market ("Market survey" refers to our assessments conducted in local stores).

\begin{tabular}{|c|c|c|}
\hline Category & Market Share (\%) & Reference \\
\hline Sunscreen & 85 & Market survey: out of 27 products, 23 are likely to contain ENP. \\
\hline Skincare/Cosmetics & 1 & Tiede et al., $2011[55]$ \\
\hline Makeup/Cosmetics & 2 & Tiede et al., 2011 [55] \\
\hline Toothpaste/Health and fitness & 78 & Market survey: Out of 79 toothpaste, 62 are likely to use ENP. \\
\hline Hair treatment/Health and fitness & 3 & Market survey: Out of 309 products 9 likely to contain ENP \\
\hline Body lotion/Health and fitness & 0.5 & Tiede et al., $2011[55]$ \\
\hline Shower spray/Health and fitness & 0.1 & Tiede et al., 2011 [55] \\
\hline Shower gel/Health and fitness & 2.5 & Market survey: Out of 162 products, 4 are likely to contain ENP. \\
\hline Tire/Automotive & 10 & Tiede et al., $2011[55]$ \\
\hline Coating/Automotive & $<1$ & Tiede et al., 2011 [55] \\
\hline Beverages/Food & 31 & Market survey: Out of 148 products, 46 are likely to use ENP. \\
\hline Instant noodles/Food & 26 & Market survey: Out of 232 products, 60 are likely to use ENP. \\
\hline Seasoning/Food & 0.1 & Based on the assumption: market share is very low, $0.1 \%$. \\
\hline Snack/Food & 21 & Market survey: Out of 247 products, 53 are likely to use ENP. \\
\hline Sweets/Food & 13 & Market survey: Out of 79 products, 10 are likely to use ENP. \\
\hline Cleaning/Home and garden & $<1$ & Tiede et al., $2011[55]$ \\
\hline Clothing and footwear & $<1$ & Tiede et al., 2011 [55] \\
\hline Household electrical appliances & $<1$ & Tiede et al., 2011 [55] \\
\hline
\end{tabular}

Emission quantity of ENP. Data on ENP concentrations, release quantity, and market share were combined to estimate the emission quantity of each ENP using Equation 1. Table 7 shows the emission quantities of ENP reaching different environmental compartments (i.e., water, air, and soil). For the aquatic environment, municipal sewerage and urban runoff are the two main ENP-accepting bodies in Singapore. The most important ENP emitted into municipal sewage were, from high to low quantity: $\mathrm{TiO}_{2}, \mathrm{ZnO}, \mathrm{SiO}_{2}$, $\mathrm{Ag}$, and $\mathrm{Au}$. For urban runoff, carbon black and $\mathrm{SiO}_{2}$ were the major components that could reach the urban runoff collection systems (e.g., collection ponds, channels, and eventually reservoirs).

In addition to entering into the aquatic environment, ENP can also be transported to soil and air compartments during the use and disposal of the products (see Table 7 for the respective release factors). Solid waste is incinerated in Singapore and only a very small portion of ENP can pass through these modern incineration plants with state-of-the-art flue gas washing and effective filtration systems [69]. The ash residue in which any remaining ENP may be collected is then transported to a landfill on Semakau Island, thus they are removed from Singapore's mainland. The aquatic environment is the main accepting body for the released ENP identified in this study.

The daily per capita release quantities obtained above can be multiplied by the number of people living in Singapore (5.3 million in 2013 [70]) or, in the case of automotive products, the number of registered vehicles $(969,910$ in 2012 [27]) to obtain the total quantity of ENP released annually into the aquatic environment of Singapore. The estimated ranges of release of the predominant ENP are: $\mathrm{TiO}_{2}$ (73.5 to $969.0 \mathrm{t} / \mathrm{y}$ ), followed by $\mathrm{ZnO}$ (1.2 to $272.0 \mathrm{t} / \mathrm{y}$ ), $\mathrm{SiO}_{2}$ (40.9 to $196.0 \mathrm{t} / \mathrm{y}$ thereof 21.2 to $29.7 \mathrm{t} / \mathrm{y}$ from road surface runoff), carbon black (21.2 to $29.7 \mathrm{t} / \mathrm{y}$, mostly from runoff), $\mathrm{Ag}$ (26.7 to $27.5 \mathrm{t} / \mathrm{y}$ ), and $\mathrm{Au}(0.002$ to $2.600 \mathrm{t} / \mathrm{y})$. 
Table 7. Summary of quantity of ENP reaching different environmental compartments.

\begin{tabular}{|c|c|c|c|c|c|c|c|c|}
\hline \multirow[t]{2}{*}{ No. } & \multirow[t]{2}{*}{ ENP Type } & \multirow[t]{2}{*}{ Product/Category } & \multirow[t]{2}{*}{$\begin{array}{c}\text { Release into } \\
\text { Water }\end{array}$} & \multicolumn{2}{|c|}{$\begin{array}{c}\text { Emission Quantity } \\
(\mathrm{g} / \mathrm{pc} / \mathrm{d})\end{array}$} & \multirow[t]{2}{*}{ Release Elsewhere } & \multicolumn{2}{|c|}{$\begin{array}{c}\text { Emission Quantity } \\
(\mathrm{g} / \mathrm{pc} / \mathrm{d})\end{array}$} \\
\hline & & & & Low & High & & Low & High \\
\hline 1 & $\mathrm{TiO}_{2}$ & $\begin{array}{l}\text { Sunscreen, automotive, } \\
\text { cleaning, skincare, } \\
\text { makeup, toothpaste, } \\
\text { shampoo, body lotion, } \\
\text { shower gel, beverages }\end{array}$ & $\begin{array}{l}\text { Down the } \\
\text { drain }\end{array}$ & $3.80 \mathrm{E}-02$ & $5.01 \mathrm{E}-01$ & $\begin{array}{l}\text { Losses in the sea, } \\
\text { solid waste }\end{array}$ & $2.30 \mathrm{E}-04$ & $2.50 \mathrm{E}-02$ \\
\hline 2 & $\mathrm{ZnO}$ & $\begin{array}{c}\text { Sunscreen, makeup, } \\
\text { skincare }\end{array}$ & $\begin{array}{c}\text { Down the } \\
\text { drain }\end{array}$ & $5.93 \mathrm{E}-04$ & $1.41 \mathrm{E}-01$ & Solid waste & $6.59 \mathrm{E}-05$ & $1.56 \mathrm{E}-02$ \\
\hline 3 & $\mathrm{Pt}$ & Skincare & $\begin{array}{l}\text { Down the } \\
\text { drain }\end{array}$ & $7.20 \mathrm{E}-07$ & $3.17 \mathrm{E}-04$ & Solid waste & $3.79 \mathrm{E}-08$ & $1.67 \mathrm{E}-05$ \\
\hline 4 & $\mathrm{Au}$ & Skincare, makeup & $\begin{array}{l}\text { Down the } \\
\text { drain }\end{array}$ & $1.21 \mathrm{E}-06$ & $1.36 \mathrm{E}-03$ & Solid waste & $2.25 \mathrm{E}-07$ & $7.33 \mathrm{E}-05$ \\
\hline 5 & $\mathrm{MnO}_{2}$ & Skincare & $\begin{array}{l}\text { Down the } \\
\text { drain }\end{array}$ & $1.52 \mathrm{E}-09$ & $1.30 \mathrm{E}-08$ & N/A & N/A & N/A \\
\hline 6 & $\mathrm{SiO}_{2}$ & $\begin{array}{c}\text { Skincare, toothpaste, } \\
\text { shower spray, beverages, } \\
\text { instant noodles, } \\
\text { seasoning, snacks }\end{array}$ & $\begin{array}{l}\text { Down the } \\
\text { drain }\end{array}$ & $1.02 \mathrm{E}-02$ & $8.59 \mathrm{E}-02$ & $\begin{array}{l}\text { Solid waste and } \\
\text { aerosol in the air }\end{array}$ & $4.12 \mathrm{E}-03$ & $9.14 \mathrm{E}-03$ \\
\hline 7 & $\begin{array}{c}\text { Alumino- } \\
\text { silicate oxides }\end{array}$ & Makeup & $\begin{array}{l}\text { Down the } \\
\text { drain }\end{array}$ & $1.80 \mathrm{E}-08$ & $1.19 \mathrm{E}-06$ & Solid waste & $4.20 \mathrm{E}-08$ & $2.77 \mathrm{E}-06$ \\
\hline 8 & Iron oxides & Makeup & $\begin{array}{l}\text { Down the } \\
\text { drain }\end{array}$ & $3.00 \mathrm{E}-08$ & $9.00 \mathrm{E}-06$ & Solid waste & $2.70 \mathrm{E}-07$ & $8.10 \mathrm{E}-05$ \\
\hline 9 & $\mathrm{Al}_{2} \mathrm{O}_{3}$ & Makeup & $\begin{array}{l}\text { Down the } \\
\text { drain }\end{array}$ & $2.40 \mathrm{E}-08$ & $7.20 \mathrm{E}-06$ & Solid waste & $5.60 \mathrm{E}-08$ & $1.68 \mathrm{E}-05$ \\
\hline 10 & $\mathrm{Cu}$ & Makeup & $\begin{array}{l}\text { Down the } \\
\text { drain }\end{array}$ & $1.08 \mathrm{E}-08$ & $1.08 \mathrm{E}-07$ & Solid waste & $2.52 \mathrm{E}-08$ & $2.52 \mathrm{E}-07$ \\
\hline
\end{tabular}


Table 7. Cont

\begin{tabular}{|c|c|c|c|c|c|c|c|c|}
\hline \multirow[t]{2}{*}{ No. } & \multirow[t]{2}{*}{ ENP Type } & \multirow[t]{2}{*}{ Product/Category } & \multirow[t]{2}{*}{$\begin{array}{c}\text { Release into } \\
\text { Water }\end{array}$} & \multicolumn{2}{|c|}{$\begin{array}{c}\text { Emission Quantity } \\
(\mathrm{g} / \mathrm{pc} / \mathrm{d})\end{array}$} & \multirow[t]{2}{*}{ Release Elsewhere } & \multicolumn{2}{|c|}{$\begin{array}{c}\text { Emission Quantity } \\
(\mathrm{g} / \mathrm{pc} / \mathrm{d})\end{array}$} \\
\hline & & & & Low & High & & Low & High \\
\hline 11 & $\mathrm{Si}$ & Makeup & $\begin{array}{l}\text { Down the } \\
\text { drain }\end{array}$ & $1.08 \mathrm{E}-08$ & $1.08 \mathrm{E}-07$ & Solid waste & $2.52 \mathrm{E}-08$ & $2.52 \mathrm{E}-07$ \\
\hline 12 & Collagen & Makeup & $\begin{array}{l}\text { Down the } \\
\text { drain }\end{array}$ & $2.00 \mathrm{E}-10$ & $2.40 \mathrm{E}-09$ & solid waste & $1.80 \mathrm{E}-09$ & $2.16 \mathrm{E}-08$ \\
\hline 13 & Carbon black * & Tire & Runoff & $5.98 \mathrm{E}-02$ & $8.38 \mathrm{E}-02$ & $\begin{array}{c}\text { Other } \\
\text { environmental } \\
\text { compartments: air } \\
\text { and soil. }\end{array}$ & $2.56 \mathrm{E}-02$ & $3.59 \mathrm{E}-02$ \\
\hline 14 & $\mathrm{SiO}_{2} *$ & Tire & Runoff & $5.98 \mathrm{E}-02$ & $8.38 \mathrm{E}-02$ & $\begin{array}{c}\text { Other } \\
\text { environmental } \\
\text { compartments: air } \\
\text { (airborne particles) } \\
\text { and soil. }\end{array}$ & $2.56 \mathrm{E}-02$ & $3.59 \mathrm{E}-02$ \\
\hline 15 & Ceramic & Car coating & $\begin{array}{l}\text { Down the } \\
\text { drain }\end{array}$ & $1.20 \mathrm{E}-04$ & $1.20 \mathrm{E}-04$ & N/A & N/A & N/A \\
\hline 16 & Nano glass & Car coating & $\begin{array}{l}\text { Down the } \\
\text { drain }\end{array}$ & $3.00 \mathrm{E}-05$ & $3.00 \mathrm{E}-05$ & N/A & N/A & N/A \\
\hline 17 & $\mathrm{Ti}$ & Home cleaning & $\begin{array}{l}\text { Down the } \\
\text { drain }\end{array}$ & $5.50 \mathrm{E}-03$ & $5.50 \mathrm{E}-03$ & N/A & N/A & N/A \\
\hline 18 & $\mathrm{Ag}$ & $\begin{array}{l}\text { Cleaning, clothing and } \\
\text { footwear, household } \\
\text { electrical appliances }\end{array}$ & $\begin{array}{l}\text { Down the } \\
\text { drain }\end{array}$ & $1.38 \mathrm{E}-02$ & $1.42 \mathrm{E}-02$ & N/A & N/A & N/A \\
\hline
\end{tabular}

* Unit: g/car/d. 


\section{Conclusions}

The nano-inventory of consumer products supplied in the Singapore retail market confirms that nanoparticle-enabled products have reached the market in sizeable quantities. The investigations were done in major Singaporean retail stores and completed through Internet searches on frequently used commercial platforms. Thus, this survey provides a good estimate of the market distribution and the use of ENP-containing consumer products in Singapore. The assessment of the potential of the various ENP being released into different aquatic environments throughout their lifetime suggests that the majority is released into wastewater and urban runoff. $\mathrm{TiO}_{2}$ and $\mathrm{SiO}_{2}$ are the most important ENP released into wastewater, whereas "traditional" ENP from tire wear is the main contributor to ENP reaching the urban runoff in Singapore.

Singapore treats all waste water and it recently introduced a program to let urban runoff pass through elementary treatment cells (e.g., vegetated swale or ponds, wetlands) for purification of this runoff and to reduce peak flow rates of related pollutants [71,72]. Thus, both release routes will face treatment processes. The emission quantities determined in this study represent the initial amount of ENP reaching the aquatic environment before these treatment processes in wastewater/water plants, where most of ENP will be removed from water [73-76]. The information presented here about ENP and their target water bodies represents a useful starting point and can be used for modeling the fate of ENP in the aquatic environment of Singapore.

\section{Acknowledgments}

This research was supported by a grant from the Public Utilities Board (PUB), Singapore's National Water Agency (PUB000ECO13000878/1).

\section{Author Contributions}

Yuanyuan Zhang coordinated the collection of data, analyzed it, and drafted the manuscript. Yu-Rui Leu supported the data collection and contributed to the manuscript discussion. Robert J Aitken conceived of the study, co-supervised the study, and contributed to the manuscript writing. Michael Riediker contributed to the study design, provided the strategy for the data collection and analysis and supervised it, and contributed to the manuscript writing.

\section{Conflicts of Interest}

The authors declare no conflict of interest.

\section{References}

1. Nanotechnology and Human Health: Scientific Evidence and Risk Governance. Available online: http://apps.who.int/iris/handle/10665/108626 (assessed on 1 July 2015). 
2. Chaudhry, Q.; Blackburn, J.; Floyd, P. A scoping study to identify gaps in environmental regulation for the products and applications of nanotechnologies.Available online: http://randd.defra.gov.uk/Default.aspx?Menu=Menu\&Module=More\&Location=None\&Complete $\mathrm{d}=0 \&$ ProjectID=13855 (assessed on 23 July 2015).

3. Aitken, R.J.; Chaudhry, M.Q.; Boxall, A.B.A.; Hull, M. In-depth reivew: Manufacture and use of nanomaterials: current status in the UK and global trends. Occup. Med. (Lond). 2006, 56, 300-306.

4. Nanomaterials in Consumer Products-Update of Products on the European Market in 2010. Available online: http://rivm.openrepository.com/rivm/handle/10029/259837 (assessed on 1 July 2015).

5. Zhang, W. Nanoscale iron particles for environmental remediation: An overview. J. Nanopart. Res. 2003, 5, 323-332.

6. USEPA. Nanomaterial Case Studies: Nanoscale Titanium Dioxide in Water Treatment and in Topical Sunscreen. Available online: http://cfpub.epa.gov/ncea/cfm/ recordisplay.cfm?deid=230972 (assessed on 1 July 2015).

7. Nowack, B.; Krug, H.F.; Height, M. 120 Years of Nanosilver History: Implications for Policy Makers. Environ. Sci. Technol. 2011, 45, 1177-1183.

8. Nanoscience and Nanotechnologies: Opportunities and Uncertainties. Available online: https://royalsociety.org/ /media/Royal_Society_Content/policy/publications/2004/9693.pdf (assessed on 1 July 2015).

9. Schmid, K.; Riediker, M. Use of nanoparticles in swiss industry: A targeted survey. Environ. Sci. Technol. 2008, 42, 2253-2260.

10. Maynard, A.D.; Aitken, R.J.; Butz, T.; Colvin, V.; Donaldson, K.; Oberdörster, G.; Philbert, M.A.; Ryan, J.; Seaton, A.; Stone, V.; et al. Safe handling of nanotechnology. Nature 2006, 444, 267-269.

11. Boxall, A.; Chaudhry, Q.; Sinclair, C.; Jones, A.; Aitken, R.; Jefferson, B.; Watts, C. Current and Future Predicted Environmental Exposure to Engineered Nanoparticles; Central Science Laboratory: Yorkshire, UK, 2007.

12. Savolainen, K.; Pylkkänen, L.; Norppa, H.; Falck, G.; Lindberg, H.; Tuomi, T.; Vippola, M.; Alenius, H.; Hämeri, K.; Koivisto, J.; et al. Nanotechnologies, engineered nanomaterials and occupational health and safety-A review. Safety Sci. 2010, 48, 957-963.

13. Breggin, L.K.; Falkner, R.; Pendergrass, J.; Porter, R.; Jaspers, N. Addressing the risks of nanomaterials under united states and european union regulatory frameworks for chemicals. In Assessing Nanoparticle Risks to Human Health; Ramachandran, G., Ed.; William Andrew: Waltham, MA, USA, 2011; pp. 195-272.

14. Lee, J.H.; Lee, S.-B.; Bae, G.N.; Jeon, K.S.; Yoon, J.U.; Ji, J.H.; Sung, J.H.; Lee, B.G.; Lee, J.H.; Yang, J.S.; et al. Exposure assessment of carbon nanotube manufacturing workplaces. Inhal. Toxicol. 2010, 22, 369-381.

15. Lorenz, C.; Von Goetz, N.; Scheringer, M.; Wormuth, M.; Hungerbühler, K. Potential exposure of German consumers to engineered nanoparticles in cosmetics and personal care products. Nanotoxicology 2011, 5, 12-29.

16. Perrenoud, A.; Gasser, M.; Rutishauser, B.R.; Gehr, P.; Riediker, M. Characterisation of nanoparticles resulting from different braking behaviours. Int. J. Biomed. Nanosci. Nanotechnol. 2010, 1, doi:10.1504/IJBNN.2010.034123. 
17. Fröhlich, E.; Roblegg, E. Models for oral uptake of nanoparticles in consumer products. Toxicology 2012, 291, 10-17.

18. Handy, R.D.; Van Den Brink, N.; Chappell, M.; Mühling, M.; Behra, R.; Dušinská, M.; Simpson, P.; Ahtiainen, J.; Jha, A.N.; Seiter, J.; et al. Practical considerations for conducting ecotoxicity test methods with manufactured nanomaterials: What have we learnt so far? Ecotoxicology 2012, 21, 933-972.

19. European Commission. Definition of a Nanomaterial. Available online: http://ec.europa.eu/ environment/chemicals/nanotech/faq/definition_en.htm (accessed on 1 July 2015.).

20. Woodrow Wilson Institute. Nanotechnology Consumer Product Inventory. Available online: http://www.nanotechproject.org/cpi/ (accessed on 1 July 2015).

21. Hansen, S.F.; Michelson, E.S.; Kamper, A.; Borling, P.; Stuer-Lauridsen, F.; Baun, A. Categorization framework to aid exposure assessment of nanomaterials in consumer products. Ecotoxicology 2008, 17, 438-447.

22. Köhler, A.R.; Som, C.; Helland, A.; Gottschalk, F. Studying the potential release of carbon nanotubes throughout the application life cycle. J. Clean. Prod. 2008, 16, 927-937.

23. Mueller, N.C.; Nowack, B. Exposure modeling of engineered nanoparticles in the environment. Environ. Sci. Technol. 2008, 42, 4447-4453.

24. Regulation (EC) No 1223/2009 of the European Parliament and of the Council of 30 November 2009 on Cosmetic Products. Available online: http://eur-lex.europa.eu/legal-content/EN/ TXT/?uri=celex:32009R1223 (accessed on 1 July 2015).

25. Vogel, U.; Savolainen, K.; Wu, Q.; Tongeren, M.V.; Brouwer, D.; Berges, M. Handbook of Nanosafety: Measurement, Exposure and Toxicology; Academic Press: Londn, UK, 2014.

26. Brake and Tire Wear Emissions From On-Road Vehicles in MOVES2014. Available online: http://www.epa.gov/otaq/models/moves/documents/420r14013.pdf (accessed on 1 July 2015).

27. Statistics In Brief 2013-Land Transport Authority. Available online: https://www.lta.gov.sg/ content/dam/ltaweb/corp/PublicationsResearch/files/FactsandFigures/Statistics $\% 20 \mathrm{in} \% 20 \mathrm{Brief} \% 2$ 02014.pdf (accessed on 1 July 2015).

28. Wijnhoven, S.W. P.; Dekkers, S.; Hagens, W.I.; de Jong, W.H. Exposure to Nanomaterials in Consumer Products. Available online: http://www.rivm.nl/milieuportaal/images/RIVMrapport_\% 27Exposure_to_nanomaterials_in_consumer_products\%27\%5B1\%5D\%5B1\%5D.pdf (accessed on 1 July 2015).

29. Overview on Promising Nanomaterials for Industrial Applications. Available online: http://www.tut.ee/public/m/Mehaanikateaduskond/Instituudid/Materjalitehnika_instituut/MTX910 0/Additional_reading/NanoMat2015.pdf(accessed on 1 July 2015).

30. AmericanElements: Silver Nanoparticles. Available online: http://www.americanelements.com/ agnp.html (accessed on 1 July 2015).

31. AzoNano: Aluminium/Aluminum Nanoparticles-Properties, Application. Available online: http://www.azonano.com/article.aspx?ArticleID=3257 (accessed on 1 July 2015).

32. AmericanElements: Zirconium Oxide Nanopowder. Available online: http://www.americanelements.com/zroxnp.html (accessed on 1 July 2015).

33. DaNa: Zirconium Dioxide. Available online: http://nanopartikel.info/en/nanoinfo/materials/ zirconium-dioxide (accessed on 1 July 2015). 
34. Uskoković, V.; Uskoković, D.P. Nanosized hydroxyapatite and other calcium phosphates: Chemistry of formation and application as drug and gene delivery agents. J. Biomed. Mater. Res. B. 2011, 96, 152-191.

35. Lahiri, D.; Ghosh, S.; Agarwal, A. Carbon nanotube reinforced hydroxyapatite composite for orthopedic application: A review. Mater. Sci. Eng. C 2012, 32, 1727-1758.

36. Du, M.; Song, W.; Cui, Y.; Yang, Y.; Li, J. Fabrication and biological application of nano-hydroxyapatite (nHA)/alginate (ALG) hydrogel as scaffolds. J. Mater. Chem. 2011, 21, 2228-2236.

37. Fauchadour, D.; Jeanson, T.; Bousseau, J.-N.; Echalier, B. Nanoparticles of Cerium OxideApplication to Coatings Technologies. Available online: http:/www.pcimag.com/articles/83469nanoparticles-of-cerium-oxide-application-to-coatings-technologies (accessed on 1 July 2015).

38. Goharshadi, E.K.; Samiee, S.; Nancarrow, P. Fabrication of cerium oxide nanoparticles: Characterization and optical properties. J. Colloid Interf. Sci. 2011, 356, 473-480.

39. Patent Application Title: Cerium Oxide Nanoparticles. Available online: http://www.faqs.org/ patents/app/20090233098 (accessed on 1 July 2015).

40. Xu, P.; Zeng, G.M.; Huang, D.L.; Feng, C.L.; Hu, S.; Zhao, M.H.; Lai, C.; Wei, Z.; Huang, C.; Xie, G.X.; et al. Use of iron oxide nanomaterials in wastewater treatment: A review. Sci. Total Environ. 2012, 424, 1-10.

41. Esteve-turrillas, F.A.; Abad-fuentes, A. Applications of quantum dots as probes in immunosensing of small-sized analytes. Biosens. Bioelectron. 2013, 41, 12-29.

42. Weir, A.; Westerhoff, P.; Fabricius, L.; Hristovski, K.; von Goetz, N. Titanium dioxide nanoparticles in food and personal care products. Environ. Sci. Technol. 2012, 46, 2242-2250.

43. Peters, R.; Kramer, E.; Oomen, A.G.; Rivera, Z.E. H.; Oegema, G.; Tromp, P.C.; Fokkink, R.; Rietveld, A.; Marvin, H.J. P.; Weigel, S.; et al. Presence of nano-sized silica during in vitro digestion of foods containing silica as a food additive. ACS Nano 2012, 6, 2441-2451.

44. Benn, T.M.; Westerhoff, P. Nanoparticle silver released into water from commercially available sock fabrics. Environ. Sci. Technol. 2008, 42, 4133-4139.

45. Cross, S.E.; Innes, B.; Roberts, M.S.; Tsuzuki, T.; Robertson, T. A.; McCormick, P. Human skin penetration of sunscreen nanoparticles: In vitro assessment of a novel micronized zinc oxide formulation. Skin Pharmacol. Phys. 2007, 20, 148-154.

46. Technical Guidance Document on Risk Assessment. Available online: http://enfo.agt.bme.hu/ drupal/en/etanfolyam/11424 (accessed on 1 July 2015).

47. Lademann, J.; Patzelt, A.; Richter, H.; Lademann, O.; Baier, G.; Breucker, L.; Landfester, K. Nanocapsules for drug delivery through the skin barrier by tissue-tolerable plasma. Laser Phys. Lett. 2013, 10, doi:10.1088/1612-2011/10/8/083001.

48. Kojima, K.; Murakami, M.; Yoshimizu, C.; Tayasu, I.; Nagata, T.; Furumai, H. Evaluation of surface runoff and road dust as sources of nitrogen using nitrate isotopic composition. Chemosphere 2011, 84, 1716-1722.

49. World Environment Day_Food Waste Facts. Available online: http://www.unep.org/wed/ quickfacts/ (accessed on 1 July 2015). 
50. Loretz, L.; Api, A.M.; Barraj, L.; Burdick, J.; Davis, D.A.; Dressler, W.; Gilberti, E.; Jarrett, G.; Mann, S.; Laurie Pan, Y.H.; et al. Exposure data for personal care products: hairspray, spray perfume, liquid foundation, shampoo, body wash, and solid antiperspirant. Food Chem. Toxicol. 2006, 44, 2008-2018.

51. Purest colloids: Colloidal Skin Conditioners by Purest Colloids. Available online: https://www.purestcolloids.com/colloidal-skin-conditioners.php (accessed on 1 July 2015).

52. Müller, R.H.; Petersen, R.D.; Hommoss, A; Pardeike, J. Nanostructured lipid carriers (NLC) in cosmetic dermal products. Adv. Drug Deliver. Rev. 2007, 59, 522-530.

53. Hyaluronic Acid Serum. Available online: http://www.ebay.com.au/bhp/hyaluronic-acid-serum (accessed on 1 July 2015).

54. Taufikurohmah, T.; Sanjaya, I.G. M.; Syahrani, A. Nanogold synthesis using matrix mono glyceryl stearate as antiaging compounds in modern cosmetics. J. Mater. Sci. Eng. A 2011,1, 857-864.

55. Tiede, K.; Westerhoff, P.; Hansen, S.F.; Fern, G.J.; Hankin, S.M.; Aitken, R.J.; Chaudhry, Q.; Boxall, A.B.A. Review of the Risks Posed to Drinking Water by Man-Made Nanoparticles. Available online: http://forskningsbasen.deff.dk/Share.external?sp=S9b311d78-5049-46a3-9a87a6a35a4c76f6\&sp=Sdtu (accessed on 1 July 2015).

56. Wik, A.; Dave, G. Environmental labeling of car tires-Toxicity to Daphnia magna can be used as a screening method. Chemosphere 2005, 58, 645-651.

57. Permitted Colouring Agents_Lists of Permitted Food Additives Available online: http://www.hc-sc.gc.ca/fn-an/securit/addit/list/3-colour-color-eng.php (accessed on 1 July 2015).

58. Opinion of the Scientific Panel on Food Additives, Flavorings, Processing Aids and Materials in Contact With Food on A Request From the Commission Related to the Safety in Use of Rutile Titanium Dioxide As An Alternative to the Presently Permitted Anat. Available online: forskningsbasen.deff.dk/Share.external?sp=Saa52aaa0-91b2-4b1d-98c9-85e56238e6a1\&sp=Sdtu (accessed on 1 July 2015).

59. Biesterbos, J.W.H.; Dudzina, T.; Delmaar, C.J.E.; Bakker, M.I.; Russel, F.G.M.; von Goetz, N.; Scheepers, P.T.J.; Roeleveld, N. Usage patterns of personal care products: important factors for exposure assessment. Food Chem. Toxicol. 2013, 55, 8-17.

60. Hall, B.; Tozer, S.; Safford, B.; Coroama, M.; Steiling, W.; Leneveu-Duchemin, M.C.; McNamara, C.; Gibney, M. European consumer exposure to cosmetic products, a framework for conducting population exposure assessments. Food Chem. Toxicol. 2007, 45, 2097-2108.

61. Loretz, L.J.; Api, A.M.; Barraj, L.M.; Burdick, J.; Dressler, W.E.; Gettings, S.D.; Han Hsu, H.; Pan, Y.H.L.; Re, T.A.; Renskers, K.J.; et al. Exposure data for cosmetic products: lipstick, body lotion, and face cream. Food Chem. Toxicol. 2005, 43, 279-291.

62. Loretz, L.J.; Api, A.M.; Babcock, L.; Barraj, L.M.; Burdick, J.; Cater, K.C.; Jarrett, G.; Mann, S.; Pan, Y.H.L.; Re, T.A.; et al. Exposure data for cosmetic products: facial cleanser, hair conditioner, and eye shadow. Food Chem. Toxicol. 2008, 46, 1516-1524.

63. Exposure Factors Handbook. Available online: http://www.osti.gov/scitech/biblio/5192412 (accessed on 1 July 2015). 
64. Gehrig, R.; Hill, M.; Buchmann, B.; Imhof, D.; Weingartner, E.; Baltensperger, U. Separate determination of $\mathrm{PM}_{10}$ emission factors of road traffic for tailpipe emissions and emissions from abrasion and resuspension processes. Int. J. Environ. Pollut. 2005, 22, doi:10.1504/IJEP.2004.005549.

65. S'poreans Drinking More Coffee: The Malaysian Times, 2013. Available online: http://www.themalaysiantimes.com.my/sporeans-drinking-more-coffee/ (accessed on 1 July 2015).

66. WHO expert consultation. Appropriate body-mass index for Asian populations and its implications for policy and intervention strategies. Lancet 2004, 363, 157-163.

67. Deurenberg, P.; Bhaskaran, K.; Lim, P.; Lian, K. Singaporean Chinese adolescents have more subcutaneous adipose tissue than Dutch Caucasians of the same age and body mass index. ASA Pac. J. Clin. Nutr. 2003, 12, 261-265.

68. Carlsen, M.H.; Blomhoff, R.; Andersen, L.F. Intakes of culinary herbs and spices from a food frequency questionnaire evaluated against 28-days estimated records. Nutr. J. 2011, 10, 1-6.

69. Walser, T.; Limbach, L.K.; Brogioli, R.; Erismann, E.; Flamigni, L.; Hattendorf, B.; Juchli, M.; Krumeich, F.; Ludwig, C.; Prikopsky, K.; et al. Persistence of engineered nanoparticles in a municipal solid-waste incineration plant. Nat. Nanotechnol. 2012, 7, 520-524.

70. National Population and Talent Division: Singapore Department of Statistics Available online: http:/www.nptd.gov.sg/portals/0/news/population-in-brief-2014.pdf (accessed on 1 July 2015).

71. Local Catchment Water Singapore. Available online: http://www.pub.gov.sg/water/Pages/ LocalCatchment.aspx (accessed on 1 July 2015).

72. ABC Waters Programme Singapore. Available online: http://www.pub.gov.sg/abcwaters/Pages/ default.aspx (accessed on 1 July 2015).

73. Kaegi, R.; Voegelin, A.; Sinnet, B.; Zuleeg, S.; Hagendorfer, H.; Burkhardt, M.; Siegrist, H. Behavior of metallic silver nanoparticles in a pilot wastewater treatment plant. Environ. Sci. Technol. 2011, 45, 3902-3908.

74. Benn, T.; Wang, Y.; Hristovski, K. Titanium nanomaterial removal and release from wastewater treatment plants. Environ. Sci. Technol. 2009, 43, 6757-6763.

75. Hou, L.; Xia, J.; Li, K.; Chen, J.; Wu, X.; Li, X. Removal of ZnO nanoparticles in simulated wastewater treatment processes and its effects on COD and $\mathrm{NH}(4)(+)-\mathrm{N}$ reduction. Water Sci. Technol. 2013, 67, 254-260.

76. Ganesh, R.; Smeraldi, J.; Hosseini, T.; Khatib, L.; Olson, B.H.; Rosso, D. Evaluation of nanocopper removal and toxicity in municipal wastewaters. Environ. Sci. Technol. 2010, 44, 7808-7813.

(C) 2015 by the authors; licensee MDPI, Basel, Switzerland. This article is an open access article distributed under the terms and conditions of the Creative Commons Attribution license (http://creativecommons.org/licenses/by/4.0/). 